OPEN ACCESS

Edited by:

Humberto Rodríguez Fuentes,

Universidad Autónoma de Nuevo

León, Mexico

Reviewed by:

Teresa Orlikowska,

Research Institute of Horticulture,

Poland

Katarzyna Turnau,

Jagiellonian University, Poland

${ }^{*}$ Correspondence:

Medhin H. Kifle

medhin7@yahoo.com

Specialty section:

This article was submitted to Crop Science and Horticulture,

a section of the journal

Frontiers in Plant Science

Received: 10 April 2015 Accepted: 18 December 2015

Published: 08 January 2016

Citation:

Kifle MH and Laing MD (2016) Isolation and Screening of Bacteria for Their Diazotrophic Potential and Their Influence on Growth Promotion of Maize Seedlings in Greenhouses.

Front. Plant Sci. 6:1225

doi: 10.3389/fpls.2015.01225

\section{Isolation and Screening of Bacteria for Their Diazotrophic Potential and Their Influence on Growth Promotion of Maize Seedlings in Greenhouses}

\author{
Medhin H. Kifle * and Mark D. Laing \\ Discipline of Plant Pathology, School of Agricultural, Earth and Environmental Sciences University of KwaZulu-Natal, \\ Pietermaritzburg, South Africa
}

Poor soil fertility is one of the major constraints for crop production. Nitrogen is the most limiting nutrient for increasing crop productivity. Therefore, there is a need to identify diazotrophic inoculants as an alternative or supplement to $\mathrm{N}$-fertilizers for sustainable agriculture. In the current study, a number of free-living diazotrophic bacteria were isolated from soils collected from maize rhizosphere and from leaves and roots of maize within the KwaZulu-Natal Province, Republic of South Africa. Ninety-two isolates were selected for further screening because they were able to grow on $\mathrm{N}$-free media containing different carbon sources. Isolates that were very slow to grow on $\mathrm{N}$-free media were discarded. The isolates were screened in vitro for diazotrophic potential tests for ammonia production and acetylene reduction. Ethylene $\left(\mathrm{C}_{2} \mathrm{H}_{4}\right)$ production was quantified and ranged from 4 to 73 nmoles of $\mathrm{C}_{2} \mathrm{H}_{4} \mathrm{~h}^{-1}$ culture $^{-1}$. The top 20 isolates were re-screened on maize seedlings, and eight isolates significantly $(P=0.001)$ enhanced some growth parameters of maize above the un-inoculated control. Isolates that showed significant effect on at least two growth parameters were identified at species or genera level. In conclusion, selected diazotrophic isolates may be potentially beneficial but they should be tested more in greenhouse and field conditions with maize to confirm their potential for application as biofertilizers.

Keywords: diazotrophs, nitrogen fixation, plant growth promotion, acetylene reduction assay

\section{INTRODUCTION}

Replacement of chemical fertilizers with biofertilizers is an attractive goal for sustainable agriculture. Nitrogen is the macro-nutrient that most frequently limits the growth and productivity of non-leguminous plants (Schepers et al., 1992) and is the most limiting factor in maize production (McCarty and Meisinger, 1997). A number of diazotrophic bacteria were previously found to interact with plants either in the rhizosphere or endophytes. Given the ability of diazotrophs to fix $\mathrm{N}$, some strains may relieve $\mathrm{N}$-deficiencies where there is inadequate application of $\mathrm{N}$ fertilizers. The genera Bacillus, Burkholderia, and Enterobacter are known to penetrate the roots of cereals and grow intercellularly as root endophytes, as well as in the rhizosphere (Reinhold-Hurek and Hurek, 1998; Wakelin and Ryder, 2004).

Some diazotrophic bacteria including those in the genera: Rhanella, Pantoea, Rhizobium, Pseudomonas, Herbaspirillum, Enterobacter, Brevundimonas, and Burkholdera were found to 
be associated to maize plants (Montañez et al., 2012). Studies confirmed that the positive effect of some diazotrophic bacterial species on non-leguminous plant yields may not only be due to nitrogen fixation but other mechanisms may also contribute to the growth responses observed in non-leguminous plants (Caballero-Mellado et al., 1992; Vessey, 2003). For example, Abiala et al. (2015) isolated a Bacillus strain with multiple growth promoting characterstics from maize rhizosphere. It is also believed that some endophytic diazotrophic bacteria contribute substantial amounts of $\mathrm{N}$ to certain graminaceous crops (Barraquio et al., 1997). When some plant seeds were inoculated with diazotrophic bacteria, enhanced seed germination, biomass, increased nitrogen, and chlorophyll content were observed in seedlings (Riggs et al., 2001; Meena et al., 2012). Egamberdiyeva (2007) reported that Pseudomonas alcaligenes inoculation stimulated the growth and nutrient uptake of maize. Inoculation of Bacillus megaterium and Bacillus mucilaginous increased the nutritional assimilation of maize plant (Wu et al., 2005).

In vitro screening techniques have been employed to select effective strains of bacteria with multiple plant growthpromotions (Ahmad et al., 2006, 2008; Çakmakçi et al., 2007). Although lack of consistency in correlation between the results obtained in vitro and in vivo have been reported (Khalid et al., 2004; Yobo et al., 2004), these techniques are simple and efficient for screening large numbers of isolates (Campbell, 1989). Combination of in vitro and in vivo screening may lead to identification of effective strains for sustainable agriculture. The current study was therefore aimed at isolating diazotrophic bacteria, their partial characterization and for preliminary screening of some growth parameters on maize seedlings in greenhouse experiment.

\section{MATERIALS AND METHODS}

\section{Bacterial Isolation}

Diazotrophic bacteria were isolated from rhizospheres, roots and leaves of maize and wheat plants collected from Cedara (Agricultural research collage, Hawick), Greytown, and Ukulinga (University of KwaZulu-Natal research farm, Pietermaritzburg), all within the KwaZulu-Natal province, Republic of South Africa. Roots and leaves were surface sterilized with 3.5\% sodium hypochlorite for $5 \mathrm{~min}$ and subsequently rinsed three times with sterile distilled water, using a modified protocol of Kloepper et al. (1991). Roots and leaves were cut into pieces and grounded with $10 \mathrm{~mL}$ of distilled water. A modified protocol of Döbereiner (1988) (N-free semi-solid media) was used to isolate rhizospheric, rhizoplane, and endophytic diazotrophs. Pure cultures of diazotrophic bacteria were then isolated by serial dilution, and plated onto $\mathrm{N}$-free (NF) media containing of either $20 \mathrm{~g}^{-1}$ of mannitol, sucrose, or malate as the carbon source; 0.2 $\mathrm{g} \mathrm{L}^{-1} \mathrm{~K}_{2} \mathrm{HPO}_{4} ; 0.2 \mathrm{~g} \mathrm{~L}^{-1} \mathrm{NaCl} ; 0.2 \mathrm{~g} \mathrm{~L}^{-1} ; \mathrm{MgSO}_{4} .7 \mathrm{H}_{2} \mathrm{O} ; 0.1 \mathrm{~g}$ $\mathrm{L}^{-1} ; \mathrm{K}_{2} \mathrm{SO}_{4} ; 5.0 \mathrm{~g} \mathrm{~L}^{-1} \mathrm{CaCO}_{3} ; 20 \mathrm{~g} \mathrm{~L}^{-1}$ agar (Merck) for solid agar media, or with $5 \mathrm{~g}$ of agar per liter for a semi-solid media. These bacteria were incubated at $30^{\circ} \mathrm{C}$ for 4 days.

Soil samples were collected from the rhizosphere of maize and wheat from different sites by uprooting the root system and placing them in plastic bags for transport to the laboratory. They were stored at $4^{\circ} \mathrm{C}$ for subsequent analysis. Excess soil was shaken off and the soil adhering to the plant roots was collected from each soil sample. Ten grams of each soil sample were transferred to a $250 \mathrm{~mL}$-Erlenmeyer flask containing $90 \mathrm{~mL}$ sterile distilled water and shaken at $150 \mathrm{rpm}$ in an orbital shaker incubator for $30 \mathrm{~min}$. Plates with NF medium with mannitol as a carbon source for diazotrophic bacteria were inoculated with $0.1 \mathrm{~mL}$ of suspensions obtained from the above dilution procedure (three replicates per dilution). The $\mathrm{pH}$ was adjusted to 6.5 using $98 \%$ sulphuric acid, and 50\% sodium hydroxide. After 5 days of incubation, colonies were transferred onto fresh $\mathrm{N}$-free media, and after 2 days were streaked out onto tryptone soy agar (TSA; Merck) plates. Bacterial isolates were selected by size and shape of colony and by their ability to grow on $\mathrm{N}$-free media. These colonies were sub-cultured onto TSA and incubated at $30^{\circ} \mathrm{C}$, purified and stored in $15 \%$ glycerol at $-80^{\circ} \mathrm{C}$.

\section{Ammonia Production Test}

Ammonia production was analyzed using the qualitative method of Ahmad et al. (2008). Bacterial isolates were tested for the production of ammonia in peptone water. Freshly grown cultures were inoculated in $10 \mathrm{~mL}$ peptone water in each tube and incubated for $48-72 \mathrm{~h}$ at $28 \pm 2^{\circ} \mathrm{C}$. Nessler's reagent $(0.5 \mathrm{~mL})$ was added in each tube. Development of a brown to yellow color was a positive test for ammonia production.

\section{Acetylene Reduction Assay (ARA)}

The basis for the assay is the fact that nitrogenase, the enzyme complex in diazotrophic microorganisms that reduces nitrogen to ammonia, also reduces acetylene to ethylene. The diazotrophic nature of all the recovered isolates was determined by ARA. Ethylene was quantified by gas chromatography (GC) and the results were expressed in nano moles of $\mathrm{C}_{2} \mathrm{H}_{4}$ produced $\mathrm{h}^{-1}$ culture $^{-1}$. One milliliter of pure culture grown in tryptone soy broth (TSB) for $24 \mathrm{~h}$ were inoculated onto $10 \mathrm{~mL}$ of nitrogenfree semi-liquid medium, with $0.5 \%$ mannitol as a carbon source, solidified by $0.3 \%$ gellan gum in $20 \mathrm{~mL}$ serum bottles and closed with a red rubber septum (SIGMA-ALDRICH, William Freeman and Co., Ltd.) and incubated for $72 \mathrm{~h}$ at $28^{\circ} \mathrm{C}$. Bottles that showed bacterial growth were assayed for acetylene reduction. Ten percent of the atmosphere in the bottles was replaced with acetylene $\left(\mathrm{C}_{2} \mathrm{H}_{2}\right)$, whereas bottles without acetylene were used as the control. After $2 \mathrm{~h}$, at $24^{\circ} \mathrm{C}, 0.25 \mathrm{~mL}$ gas samples were taken from each vial and analyzed for amount of ethylene formed using a gas chromatography. These processes were repeated three times from same vial and average were taken for the statistical analysis. A gas chromatograph (Hewlett-Packard 5830A) fitted with a 2-2.1 mm, 80-100 mesh, Poropak R column was used and the oven temperature was adjusted to $70^{\circ} \mathrm{C}$. Injection and flame-ionization detector temperatures were adjusted to $150^{\circ} \mathrm{C}$. Nitrogen carrier gas flow rate was adjusted to $50 \mathrm{~mL} \mathrm{~min}^{-1}$.

\section{Source of Seeds}

Seeds of a white maize cultivar, Mac are Medium Pearl (an open pollinated variety), were purchased from McDonalds Seeds ${ }^{\circledR}$ (MacDonald's Seeds (Ltd).P.O. Box 40, Mkondeni, 3212, 
Pietermaritzburg, Republic of South Africa) and were used throughout the experiment.

\section{Inoculum Preparation}

Bacterial isolates were grown in $100 \mathrm{~mL}$ Erlenmeyer flasks each containing a $25 \mathrm{~mL}$ tryptic soy broth (TSB; Merck) for $3 \mathrm{~d}$ at $28 \pm 2^{\circ} \mathrm{C}$ in a shaker at $150 \mathrm{rpm}$. Flasks were inoculated with bacteria previously grown in TSA for $48 \mathrm{~h}$. After $3 \mathrm{~d}$ bacteria were harvested by centrifugation using a Beckman J2-HS Centrifuge (Beckman Coulter Inc. $4300 \mathrm{~N}$ Harbor Boulevard, Box 3100, Fullerton, California, 92834-300, USA) at $9000 \mathrm{rpm}$ for $15 \mathrm{~min}$. The broth was decanted and bacterial pellets were re-suspended in sterile distilled water. Bacterial cells were then counted using a plate dilution technique on TSA plates, and adjusted to a concentration of $10^{8}$ colony forming unit (cfu) $\mathrm{mL}^{-1}$ of water.

\section{Seed Treatment}

Twenty out of 92 bacterial isolates which produced relatively high $\mathrm{C}_{2} \mathrm{H}_{4}$ levels were selected for further greenhouse screening on maize seedlings. Final cell pellets were diluted with sterile distilled water and cell numbers were adjusted to $2.4 \times 10^{8} \mathrm{cfu}$ $\mathrm{mL}^{-1}$ for each of the bacterial isolates, as determined by serial dilution and plating. Two grams of a sticker, gum arabic, were dissolved in $100 \mathrm{~mL}$ of bacterial suspension, stirred, and allowed to stand for $1 \mathrm{~h}$. This allowed the substance to dissolve and form a homogeneous suspension. Seed coating took place in a plastic bag. The bag was filled with $200 \mathrm{~g}$ seeds. The bacterial sticker suspension was added at a rate of $0.1 \mathrm{~mL} \mathrm{~g}^{-1}$ of seeds in order to increase the number of bacteria stuck onto each seed. The bag was closed in such a way to trap air as much as possible. The bag was shaken for $2 \mathrm{~min}$, until all the seeds were uniformly wetted with the sticker suspension. The bag was opened and the seed spreads onto paper towels and airdried overnight. Treated maize seeds were planted on pine bark artificial growing medium. Composition of the composted pine bark growing medium analyzed by KwaZulu-Natal Agriculture and Environmental Affairs (KZN Agriculture and Environmental Affairs, Private Bag X9059, Pietermaritzburg, 3200, Republic of South Africa) is as follows: $12.39 \mathrm{C}(\%) ; 0.11 \mathrm{~S}(\%) ; 0.43 \mathrm{~N}(\%)$; $0.61 \mathrm{Ca}(\%) ; 0.10 \mathrm{Mg}(\%) ; 0.28 \mathrm{~K}$ (\%); $0.18 \mathrm{P}(\%) ; 25.07$ Moisture (\%); $405.0 \mathrm{Na}\left(\mathrm{mg} \mathrm{kg}^{-1}\right) ; 73.0 \mathrm{Zn}\left(\mathrm{mg} \mathrm{kg}^{-1}\right) ; 16.7 \mathrm{Cu}\left(\mathrm{mg} \mathrm{kg}^{-1}\right)$; 802 $\mathrm{Mn}\left(\mathrm{mg} \mathrm{kg}^{-1}\right) ; 12293 \mathrm{Fe}\left(\mathrm{mg} \mathrm{kg}^{-1}\right) ; 7120 \mathrm{Al}\left(\mathrm{mg} \mathrm{kg}^{-1}\right)$.

\section{Measurements of Stomatal Conductance and Chlorophyll Content Index}

Greenhouse measurements of stomatal conductance and leaf chlorophyll were made on 8 weeks old seedlings. Leaf stomatal conductance was measured with a portable porometer (SC-1 Leaf Porometer, Decagon Devices, Inc., 2365 NE Hopkins Court, Pullman, WA 99163, USA). Stomatal conductance readings were made between 9:00 am and 3:00 pm on sunny days on 10 leaves of each pot of nine plants per treatment. Chlorophyll was measured using a portable, handheld device called chlorophyll meter (CCM-200 Plus, Opti-Science Inc., 8 Winn Avenue, Hudson, NH, USA, 03051; that estimates the chlorophyll content of leaves).
Measurements were made on eight leaves of each pot of nine plants per treatment.

\section{DNA Extraction and 16S rRNA Sequence Analysis}

One $\mathrm{mL}$ of $24 \mathrm{~h}$ bacterial culture was centrifuged at 14,000 relative centrifugal force ( $\mathrm{rcf}$ ) for $5 \mathrm{~min}$. The pellet was suspended in $25 \mu \mathrm{L}$ of $(10 \mathrm{mM})$ Tris and $1 \mathrm{~mL}$ of buffer was added and incubated at $60^{\circ} \mathrm{C}$ for $1 \mathrm{~h}$. One milliliter of CTAB buffer was added and gently mixed. Then the bacterial-buffer suspension were divided into two in $1.5 \mathrm{~mL}$ tubes, and $500 \mu \mathrm{L}$ of chloroformiso-amyl alcohol was added and mixed gently, and the resultant mixture was centrifuged at $14,000 \mathrm{rcf}$ for $10 \mathrm{~min}$. By avoiding the layer of impurities, $900 \mu \mathrm{l}$ of clear supernatant was removed as the sample. To this, $600 \mu \mathrm{l}$ of propan-2-ol was added and refrigerated at $-20^{\circ} \mathrm{C}$ for $1 \mathrm{~h}$. It was centrifuged for $15 \mathrm{~min}$ at $4000 \mathrm{rcf}$ and the supernatant was discarded. The pellet were washed with $50 \mu \mathrm{l}$ of $70 \%$ ethanol solution and dried in a laminar flow with lid of the tube being left open for $30 \mathrm{~min}$. The pellet was then suspended in $50 \mu \mathrm{L}$ of $10 \mathrm{mM}$ Tris $(\mathrm{pH}$ 8) or $0.5 \mathrm{X} \mathrm{TE}$ buffer. At this point the DNA purity and quality were checked on the nano drop UV spectrophotometer equipment (nano drop 1000, Inqaba Biotech, P.O.Box 1435, Hatfield 0028, Pretoria, South Africa) and a $5 \mu \mathrm{L}$ sample was run on $0.8 \%$ agarose gel [SeakemLE Agarose, Whitehead Scientific (Pty) Ltd www.whitesci.co.za] stained with SYBRSafe nucleic acid stain (Invitrogen) stained with SYBRSafe nucleic acid stain (Invitrogen), with a GeneRuler $1 \mathrm{~kb}$ DNA Ladder Plus molecular weight marker (Thermo Fisher Scientific Inc., 81 Wyman street, Waltham, MA 02454, US) to confirm the presence, size and quality of genomic DNA. Once the purity of the DNA was checked, it was sent to the Central Analytic Facility, Stellenbosch University, South Africa for sequencing and BLAST identification. The BLAST identifications were then confirmed by matrix assisted laser desorption ionization-time of flight (Maldi-TOF) classification [Brucker Daltonik Maldi-TOF Biotyper (www.bruker.com)].

\section{Bruker Daltonik Maldi Biotyper Classification}

Bacterial cultures were sub-cultured on $10 \%$ TSA for $24 \mathrm{~h}$ at $30^{\circ} \mathrm{C}$. A single bacterial colony were taken and placed into a $2 \mathrm{~mL}$ eppendorf tube with $300 \mu \mathrm{L}$ of ultra-pure water, and $900 \mu \mathrm{L}$ of pure ethanol were added, mixed and the suspension was centrifuged at 14,000 $\mathrm{rcf}$ for $2 \mathrm{~min}$. A small pellet of bacterial cells was visible at the bottom of the tube. The liquid was removed, and the pellet was briefly re-spun followed by the removal of residual ethanol. It was then re-suspended in $10 \mu \mathrm{L}$ of $70 \%$ formic acid, and $10 \mu \mathrm{L}$ of aceto-nitrile was added, and the sample was vortexed briefly. The mixture was centrifuged for $2 \mathrm{~min}$ at 14,000 $\mathrm{rcf}$, and the supernatant transferred into a clean micro-tube. The sample to be analyzed was warmed to room temperature, and a $1 \mu \mathrm{L}$ sample was spotted onto a steel target plate (Bruker Daltonics Inc., Billerica, MA, USA) and gently mixed with $2 \mu \mathrm{L}$ of matrix solution. 
TABLE 1 | Nitrogenase activity of the bacterial isolates measured by acetylene reduction assay (ARA).

\begin{tabular}{|c|c|c|c|c|c|c|c|c|}
\hline \multirow{2}{*}{$\begin{array}{l}\text { Isolates } \\
\text { Broth }\end{array}$} & \multicolumn{2}{|c|}{$\mathrm{nmol}$ of $\mathrm{C}_{2} \mathrm{H}_{4} \mathrm{~h}^{-1}$ culture ${ }^{-1}$} & \multirow{2}{*}{$\begin{array}{c}\text { Isolates } \\
\text { M12 }\end{array}$} & \multicolumn{2}{|c|}{$\mathrm{nmol}$ of $\mathrm{C}_{2} \mathrm{H}_{4} \mathrm{~h}^{-1}$ culture $^{-1}$} & \multirow{2}{*}{$\begin{array}{c}\text { Isolates } \\
\text { Bt12 }\end{array}$} & \multicolumn{2}{|c|}{$\mathrm{nmol}$ of $\mathrm{C}_{2} \mathrm{H}_{4} \mathrm{~h}^{-1}$ culture } \\
\hline & 0.32 & a & & 21.86 & cdefghijklmn & & 29.01 & ghijklmnop \\
\hline Bt14 & 4.81 & $a b$ & StB12 & 21.91 & cdefghijklmn & $\mathrm{Bt7}$ & 29.46 & ghijklmnop \\
\hline M11 & 6.20 & $a b$ & $\mathrm{~V}_{1}$ & 21.91 & cdefghijklmn & StB8 & 29.87 & ghijklmnop \\
\hline Mr2 & 6.24 & $a b$ & $\mathrm{Br} 2$ & 21.96 & cdefghijklmn & G3 & 31.78 & hijklmnopq \\
\hline SB1 & 6.46 & $a b$ & Bt1 & 21.96 & cdefghijklmn & V3 & 31.99 & ijklmnopq \\
\hline Mr63 & 6.51 & $a b$ & RB1 & 21.96 & cdefghijklmn & Mr27 & 32.27 & ijklmnopq \\
\hline Bt10 & 7.29 & $a b c$ & Bt15 & 22.01 & cdefghijklmn & V14 & 32.39 & ijklmnopqr \\
\hline Bt3 & 7.32 & $a b c$ & RB6 & 22.01 & cdefghijklmn & Mr57 & 32.77 & jklmnopqr \\
\hline Mr141 & 7.61 & $a b c$ & V12 & 22.01 & cdefghijklmn & Mr34 & 33.04 & klmnopqr \\
\hline Mr20 & 7.90 & $a b c$ & Mr148 & 22.02 & cdefghijklmn & $\mathrm{Bt} 4$ & 33.26 & klmnopqr \\
\hline Mr25 & 9.10 & abcd & RB2 & 22.06 & cdefghijklmn & Bt5 & 33.49 & Imnopqr \\
\hline Mr8 & 9.76 & abcde & StB7 & 22.06 & cdefghijklmn & V20 & 33.58 & Imnopqr \\
\hline StB3 & 10.46 & abcde & LB7 & 22.11 & cdefghijklmn & Bt11 & 33.69 & Imnopqr \\
\hline V15 & 10.96 & abcde & Bt9 & 22.15 & cdefghijklmn & Mr21 & 33.94 & mnopqrs \\
\hline Mr53 & 12.26 & abcdef & Bt6 & 22.20 & cdefghijklmn & StB13 & 35.09 & nopqrst \\
\hline Mr35 & 12.29 & abcdef & Bt8 & 22.20 & cdefghijklmn & V10 & 35.33 & nopqrst \\
\hline E9 & 12.66 & abcdef & V2 & 22.20 & cdefghijklmn & Mr150 & 35.54 & nopqrstu \\
\hline Mr38 & 15.40 & bcdefg & StB17 & 22.30 & cdefghijklmn & Mr131 & 37.13 & nopqrstu \\
\hline Mr58 & 15.96 & bcdefg & V6 & 22.40 & cdefghijklmn & StB1 & 37.23 & nopqrstu \\
\hline Mr6 & 16.44 & bcdefgh & M9 & 22.41 & cdefghijklmn & Mr37 & 38.82 & opqrstuv \\
\hline V5 & 17.02 & bcdefghi & V7 & 22.45 & cdefghijklmn & a2 & 42.00 & pqrstuv \\
\hline Mr16 & 17.22 & bcdefghi & LB9 & 22.55 & cdefghijklmn & a3 & 45.10 & qrstuv \\
\hline V4 & 17.25 & bcdefghij & $x$ & 22.80 & colefghijklmn & B1 & 45.84 & qrstuv \\
\hline Mr19 & 17.32 & bcdefghij & D6 & 24.19 & defghijkkmno & $\mathrm{a} 61$ & 46.69 & qrstuv \\
\hline Mr13 & 17.38 & bcdefghij & Mr17 & 24.19 & defghijklmno & a5 & 47.28 & rstuv \\
\hline $\mathrm{Mr} 7$ & 17.53 & bcdefghij & Mr22 & 24.73 & efghijklmno & LB5 & 48.36 & stuv \\
\hline Mr121 & 17.76 & bcdefghijk & Mr9 & 25.09 & efghijklmno & L1 & 48.75 & tuv \\
\hline Mr55 & 18.22 & bcdefghijkl & V18 & 25.20 & efghijklmno & $\mathrm{a} 6$ & 49.88 & uv \\
\hline LB2 & 18.75 & bcdefghijklm & V17 & 27.48 & fghijklmnop & StB5 & 52.37 & v \\
\hline V13 & 19.05 & bcdefghijklm & V19 & 28.40 & ghijklmnop & V16 & 65.15 & w \\
\hline $\mathrm{Bt2}$ & 21.86 & cdefghijklmn & V11 & 28.82 & ghijklmnop & V9 & 73.20 & w \\
\hline CV\% & 30.4 & & & & & & & \\
\hline DMRT & 12.035 & & & & & & & \\
\hline Sed & 6.101 & & & & & & & \\
\hline$F$-test & 9.662 & & & & & & & \\
\hline$P$-value & $<0.001$ & & & & & & & \\
\hline
\end{tabular}

Means with the same letter are not significantly different at $P \leq 0.05$. Each treatment was replicated three times $(n=3)$. Each treatment vial was sampled three times.

\section{Experimental Design}

Maize seedlings treated with bacterial isolates were watered every day with $500 \mathrm{~mL}$ nutrient solution containing: $0.11 \mathrm{~mL}$ $\mathrm{L}^{-1} \mathrm{H}_{3} \mathrm{PO}_{4} ; 0.13 \mathrm{~g} \mathrm{~L}^{-1} \mathrm{KOH} ; 0.14 \mathrm{~g} \mathrm{~L}^{-1} \mathrm{~K}_{2} \mathrm{SO}_{4} ; 0.74 \mathrm{~g} \mathrm{~L}^{-1}$ $\mathrm{CaCl}_{2} .2 \mathrm{H}_{2} \mathrm{O} ; 0.10 \mathrm{~g} \mathrm{~L}^{-1} \mathrm{MgSO}_{4} .7 \mathrm{H}_{2} \mathrm{O}$; and $0.02 \mathrm{~g} \mathrm{~L}^{-1}$ of micronutrients (MICROPLEX ${ }^{\circledR}$; Ocean Agriculture (Pty) Ltd, P.O. Box 741, Mulders drift, 1747, South Africa). There were two controls: one was untreated and supplemented with a soluble fertilizer NPK (3:1:3 [38] complete) which was parched from Ocean Agriculture (Pty) Ltd, P.O. Box 741, Mulders drift, 1747 , South Africa at a rate of $1 \mathrm{gL}^{-1}$ and the second was untreated control and supplemented with MICROPLEX ${ }^{\circledR}$ nutrient solution. Each treatment consisted of three pots with a top diameter of $200 \mathrm{~mm}$ that held $2 \mathrm{~kg}$ of composted pine bark.
Each pot was seeded with five seeds. The seedlings were thinned to three plants per pot. Pots with each of the 20 isolates were watered every day with an equal amount of a nutrient solution containing phosphorus and potassium of levels adjusted to the full recommended amounts. The experiment was arranged in a randomized complete block design (RCBD), replicated three times. Two months after planting, chlorophyll and stomatal conductance were measured and plants were harvested and dry weight was taken after the biomass was dried in an oven for $72 \mathrm{~h}$ at $70^{\circ} \mathrm{C}$.

\section{Statistical Analysis}

Experiments were repeated twice, unless otherwise stated. Data were analyzed using GenStat executable release 14th edition 
TABLE 2 | Influence of maize seeds inoculation with diazotrophic bacteria on some growth parameters of 2 months seedlings in greenhouse experiment.

\begin{tabular}{|c|c|c|c|c|c|c|c|c|c|}
\hline \multirow{2}{*}{$\begin{array}{l}\text { Bacterial } \\
\text { isolates }\end{array}$} & \multicolumn{2}{|c|}{$\begin{array}{l}\text { Chlorophyll content } \\
\text { index }\end{array}$} & \multirow{2}{*}{$\begin{array}{c}\text { \%Over } \\
\text { control } \\
-\end{array}$} & \multicolumn{2}{|c|}{$\begin{array}{l}\text { Dry } \\
\text { weight(g) }\end{array}$} & \multirow{2}{*}{$\begin{array}{c}\% \text { Over } \\
\text { control } \\
-\end{array}$} & \multicolumn{2}{|c|}{$\begin{array}{l}\text { Stomatal conductance } \\
\left(\mathrm{m} \mathrm{mol} \mathrm{m}-2 \mathrm{~s}^{-1}\right)\end{array}$} & \multirow{2}{*}{$\begin{array}{c}\% \text { Over } \\
\text { control } \\
-\end{array}$} \\
\hline & 4.45 & a & & 2.77 & $\mathrm{a}$ & & $54.2(1.733)$ & $a$ & \\
\hline Mr21 & 5.08 & $a b$ & 14.16 & 3.63 & $a b$ & 31.05 & $121.6(2.085)$ & $a b c$ & 124.35 \\
\hline Mr131 & 5.24 & $a b c$ & 17.75 & 3.62 & $a b$ & 30.69 & $122.5(2.086)$ & $a b c$ & 126.01 \\
\hline Bt11 & 5.38 & $a b c d$ & 20.90 & 3.63 & $a b$ & 31.05 & $122.5(2.087)$ & $a b c$ & 126.01 \\
\hline Mr150 & 5.59 & abcde & 25.62 & 4.13 & abcd & 49.10 & $142.0(2.152)$ & abcd & 161.99 \\
\hline StB1 & 5.83 & abcde & 31.01 & 5.17 & bcd & 86.64 & $137.7(2.127)$ & $a b c$ & 154.06 \\
\hline StB13 & 5.95 & abcdef & 33.71 & 3.79 & $a b c$ & 36.82 & $130.3(2.115)$ & $a b c$ & 140.41 \\
\hline Mr37 & 6.08 & abcdef & 36.63 & 3.72 & $a b c$ & 34.30 & $147.3(2.165)$ & abcd & 171.77 \\
\hline V20 & 6.11 & abcdef & 37.30 & 5.85 & $\mathrm{~cd}$ & 111.19 & $147.6(2.169)$ & abcd & 172.32 \\
\hline V10 & 6.21 & abcdefg & 39.55 & 5.79 & $\mathrm{~cd}$ & 109.03 & $134.6(2.129)$ & $a b c$ & 148.34 \\
\hline A61 & 6.28 & bcdefg & 41.12 & 6.23 & d & 124.91 & $206.5(2.295)$ & cde & 281.00 \\
\hline $\mathrm{A} 2$ & 6.37 & bcdefg & 43.15 & 5.84 & $\mathrm{~cd}$ & 110.83 & $198.3(2.274)$ & cde & 265.87 \\
\hline B1 & 6.52 & bcdefg & 46.52 & 3.80 & $a b c$ & 37.18 & $244.1(2.383)$ & de & 350.37 \\
\hline A6 & 6.71 & bcdefg & 50.79 & 3.41 & $a b$ & 23.10 & $218.1(2.335)$ & cde & 302.40 \\
\hline A5 & 7.03 & cdefg & 57.98 & 2.42 & a & -12.64 & $188.8(2.253)$ & bcde & 248.34 \\
\hline A3 & 7.06 & colefg & 58.65 & 5.26 & bcd & 89.89 & $219.3(2.341)$ & cde & 304.61 \\
\hline LB5 & 7.11 & defg & 59.78 & 5.51 & bcd & 98.92 & $203.4(2.278)$ & cde & 275.28 \\
\hline L1 & 7.26 & efg & 63.15 & 5.85 & $\mathrm{~cd}$ & 111.19 & $206.2(2.281)$ & cde & 280.44 \\
\hline V16 & 7.70 & $\mathrm{fg}$ & 73.03 & 5.99 & d & 116.25 & $265.0(2.423)$ & e & 388.93 \\
\hline V9 & 7.72 & $\mathrm{fg}$ & 73.48 & 2.80 & a & 1.08 & $253.3(2.404)$ & e & 367.34 \\
\hline StB5 & 8.03 & $g$ & 80.45 & 3.48 & $a b$ & 25.63 & 244.7 (2.386) & de & 351.48 \\
\hline NPK & 13.62 & $\mathrm{~h}$ & 206.07 & 9.90 & e & 257.40 & $517.5(2.712)$ & $f$ & 854.80 \\
\hline CV\% & 14 & & & 23.9 & & & 23.2 & & \\
\hline DMRT & 1.544 & & & 1.833 & & & 90.41 & & \\
\hline SED & 0.765 & & & 0.908 & & & 43.00 & & \\
\hline$P$ & $<0.001$ & & & $<0.00$ & & & $<0$ & & \\
\hline
\end{tabular}

Means with the same letters in the same column are not significantly different at $P<0.05$; values in parentheses are transformed data using log base 10 for the stomatal conductance. Means were calculated from $n=3$ for dry weight, $n=24$ for chlorophyll content index, and $n=30$ for stomatal conductance.

statistical analysis software. Significant differences between treatments were determined using Duncan's multiple range test at $5 \%$ significant level.

\section{RESULTS}

\section{Isolation and Preliminary Screening of Bacterial Diazotrophs}

There were differences between diazotrophic isolates, in their ability to grow on semi-solid $\mathrm{N}$-free medium, and using $\mathrm{D}$ mannitol, D-malate or sucrose as carbon sources. Bacterial growth were considered slow when the mass doubling time was longer than $10-12 \mathrm{~h}$ and considered well when the mass doubling time was less than $10 \mathrm{~h}$. All these isolates were able to grow well on the $\mathrm{N}$-free semi-liquid medium when sucrose was used as the carbon source, and generated ammonia in peptone water. About $20 \%$ of the bacterial isolates grew well on $\mathrm{N}$-free media with D-mannitol, sucrose, or malate as growth substrates. Approximately, $80 \%$ of the bacterial isolates showed slow growth on $\mathrm{N}$-free medium with $\mathrm{D}$-mannitol or malate.

\section{Acetylene Reduction Assay (ARA)}

All the isolates exhibited nitrogenase activity, but the level of activity varied with different isolates (Table 1). Approximately $17 \%$ of the isolates produced very little amount $\mathrm{C}_{2} \mathrm{H}_{4}$, no more than the control; $66 \%$ of the isolates produced significantly $(P<$ 0.001) more $\mathrm{C}_{2} \mathrm{H}_{4}$ compared to the control ( $\mathrm{N}$-free semi-liquid medium). The 20 isolates which produced relatively high levels of $\mathrm{C}_{2} \mathrm{H}_{4}$ were further screened in the greenhouse.

\section{Effect of Diazotrophic Inoculation on Chlorophyll Content Index, Dry Weight and Stomatal Conductance}

Of the 20 diazotrophic isolates, about $50 \%$ showed significantly higher $(P<0.001)$ chlorophyll content index, stomatal conductance and dry weight, relative to the untreated control (Table 2). The rest of these isolates had no effect $(P<0.05)$ on the above parameters. Plants of the untreated control showed the lowest stomatal conductance, chlorophyll level and dry weight and plants of the $100 \%$ NPK fertilized (NPK control) the highest (Table 2). Isolate StB5 had the highest chlorophyll content index 
TABLE 3 | Affiliation of the isolates in the GenBank and the identification of the closest type strain based on the 16S rRNA gene sequencing and Bruker Daltonik MALDI-TOF Biotyper classification.

\begin{tabular}{lll}
\hline Isolates & 16S rRNA similarities (highest match) & BrukerMALDI biotype (highest score) \\
\hline V16 & Bacillus megaterium Strain As-30 (97\%) & Bacillus sp. (1.722) \\
A5 & Burkholderia sp. IBP-VNS127 (99\%) & Burkholderia sp. (1.867) \\
V9 & Burkholderia ambifaria (99\%) & Burkholderia ambifaria (2.462) \\
L1 & Enterobacter cloacae Strain G35-1(98\%) & Enterobacter cloacae (2.327) \\
A2 & Klebsiella variicola (99\%) & Klebsiella variicola (2.243) \\
LB5 & Pantoea ananatis (97\%) & Pantoea ananatis (2.268) \\
A3 & Pseudomonas nitroreducens Strain R5-791 (99\%) & Pseudomonas sp. (1.901) \\
A6 & Pseudomonas nitroreducens (99\%) & Pseudomonas sp. (1.96) \\
B1 & Pseudomonas nitroreducens (99\%) & Pseudomonas nitroreducens (2.034) \\
StB5 & Pseudomonas nitroreducens Strain R5-791 (99\%) & Pseudomonas sp. (1.989) \\
A61 & Pseudomonas nitroreducens (99\%) & Pseudomonas sp. (1.882) \\
\hline
\end{tabular}

and stomatal conductance but its dry weight was not significantly higher than in the non-inoculated control. The highest dry weight was obtained in the seedlings inoculated with V16 and L1; their chlorophyll content index and stomatal conductance were significantly higher than in control plants.

\section{Identification of Diazotrophic Isolates}

Comparative analyses of nucleotide sequences of amplified 16S rRNA fragments, using a BLAST approach, revealed that some of the isolates with 99\% sequence accuracy. Isolates StB5, A3, A6, B1, and A61 demonstrated this accuracy with Pseudomonas nitroreducens, A5 with Burkholderia sp., V9 with Burkholderia ambifaria, and A2 with Klebsiella variicola. Isolate L1 showed 98\% similarity with Enterobacter cloacae; V16 (97\%) with B. megaterium and LB5 (97\%) with Pantoea ananatis (Table 3). With laser desorption ionization-time of flight (Maldi-TOF) classification system, a score of $\geq 2.000$ indicates species level identification, a score of 1.700-1.999 indicates identification to the genus level, and a score of $<1.700$ is interpreted as no identification. Isolates StB5, A3, A6, and A61 were identified as Pseudomonas sp with MALDI-TOF scores of 1.98, 1.90, 1.96, and 1.88 , respectively. Isolate $\mathrm{B} 1$ (2.03) as $P$. nitroreducens, V9 (2.46) as Burkholderia ambiferia and A5 (1.86) were identified as Burkholderia sp, isolate L1 (2.33) as E. cloacae, isolate V16 (1.72) as Bacillus sp, A2 (2.24) as K. variicola and isolate LB5 (2.27) as Pantoea ananatis. An independent identification of these isolates, based on 16S rRNA gene and Maldi-TOF biotyper, confirmed their identity to species and genera level.

\section{DISCUSSION}

Isolation and screening for potential diazotrophic bacteria are crucial steps in research on biofertilizers. In order to discover efficient nitrogen fixing bacteria, there is a need to develop simple, inexpensive and quick procedures with repeatable and reliable results (Döbereiner, 1988). Such as an in vitro screening procedure (growth on $\mathrm{N}$-free semi-solid media, ARA, and the ammonia production test) and the combinations of which provides rapid and repeatable results. All the isolates proved to be nitrogen fixers. Though it is difficult to compare the nitrogenase activity of bacterial strains studied in this work with the results obtained by others, a study by Różycki et al. (1999) showed similar results of nitrogenase activity by some of diazotrophic isolates belonging to the genera Pseudomonas and Bacillus.

About $50 \%$ of the best isolates used in this study were identified as Pseudomonas. In another study, the genera of Pseudomonas and Enterobacter were reported to be dominant in maize cultivars (Rodríguez-Blanco et al., 2015). Moreover, Berge et al. (1991) reported that an E. cloacae was the most abundant diazotrophic bacterium in the rhizosphere of maizegrowing soils in France. Klebsiella and Burkholderia were also dominant genera both in roots and rhizosphere of maize (Arruda et al., 2013). Estrada et al. (2002) isolated a strain of endophytic, $\mathrm{N}_{2}$-fixing Burkholderia sp. associated with maize in Mexico. Similarly, Perin et al. (2006) isolated Burkholderia sp. from the rhizosphere of maize. The predominance of these genera both in the soil and in the root zone may be due to low nutritional requirements, its capacity to utilize numerous complex of organic substrates (Krotzky and Werner, 1987) and high tolerance to low pH (Eckford et al., 2002).

In this study, some of the bacterial isolates with high nitrogenase activity were found to improve chlorophyll content, stomatal conductance and dry weight in maize. All the tested isolates showed increases (124.4-351.5\%) in stomatal conductance, nine isolates showed (86.6-24.9\%) increases in dry weight, and 11 of the isolates $(41.12-80.45 \%)$ increases in chlorophyll content index over the control. Diazotrophic microbes isolated either from soil or endophytes increased sweet corn biomass both in greenhouse and field trials (Mehnaz and Lazarovits, 2006; Mehnaz et al., 2010). In another study, interaction of diazotrophic plant growth promoting rhizobacteria with sugar cane, cotton, wheat, rice, and maize significantly increased the vegetative growth and grain yield (Kennedy et al., 2004). Likewise, maize plants inoculated with endophytic diazotrophs such as (Herbaspirillum sp, Psuedomonas sp., and Burkholderia vietnamienis) gained greater early biomass and 
higher rates of net $\mathrm{CO}_{2}$ assimilation than the un-inoculated control (Knoth et al., 2013). Furthermore, dry matter of maize increased by $25-54 \%$ after inoculation with strains Achromobacter sp., Burkholdria sp. and Arthrobacter sp. (Arruda et al., 2013). In this study, inoculation of maize seeds with Burkholderia ambifaria (V9), Bacillus sp. (V16), P. nitroreducens (B1), Pseudomonas spp. (A3, A6, A61, StB5), E. cloacae (L1), P. ananatis (LB5), and Klebsiella variicola (A2) enhanced stomatal conductance and chlorophyll content index compared to the control. The increases could be a result of increased leaf $\mathrm{N}$ through nitrogen fixation by these diazotrophs. Nitrogen fixed by diazotrophic bacteria may not fully replace chemical fertilizers however; use of diazotrophic bacterial inoculants may be an important factor for sustainable agriculture.

\section{REFERENCES}

Abiala, M., Odebode, A., Hsu, S., and Blackwood, C. (2015). Phytobeneficial properties of bacteria isolated from the rhizosphere of maize in southwestern nigerian soils. Appl. Environ. Microbiol. 81, 4736-4743. doi: 10.1128/AEM.00570-15

Ahmad, F., Ahmad, I., Aqil, F., Ahmed Wani, A., and Sousche, Y. S. (2006). Plant growth promoting potential of free-living diazotrophs and other rhizobacteria isolated from northern indian soil. Biotechnol. J. 1, 1112-1123. doi: 10.1002/biot.200600132

Ahmad, F., Ahmad, I., and Khan, M. (2008). Screening of free-living rhizospheric bacteria for their multiple plant growth promoting activities. Microbiol. Res. 163, 173-181. doi: 10.1016/j.micres.2006.04.001

Arruda, L., Beneduzi, A., Martins, A., Lisboa, B., Lopes, C., Bertolo, F., et al. (2013). Screening of rhizobacteria isolated from maize (zea mays L) in Rio grande do sul state (south Brazil) and analysis of their potential to improve plant growth. Appl. Soil Ecol. 63, 15-22. doi: 10.1016/j.apsoil.2012.09.001

Barraquio, W., Revilla, L., and Ladha, J. (1997). Isolation of endophytic diazotrophic bacteria from wetland rice. Plant Soil 194, 5-24. doi: 10.1023/a:1004246904803

Berge, O., Heulin, T., and Balandreau, J. (1991). Diversity of diazotroph populations in the rhizosphere of maize (Zea mays L) growing on different French soils. Biol. Fertil. Soils 11, 210-215. doi: 10.1007/bf00335769

Caballero-Mellado, J., Carcano-Montiel, M., and Mascarua-Esparza, M. (1992). Field inoculation of wheat (Triticum aestivum) with Azospirillum brasilense under temperate climate. Symbiosis13, 243-253.

Çakmakçi, R., Erat, M., Erdogan, U., and Dönmez, M. F. (2007). The influence of plant growth-promoting rhizobacteria on growth and enzyme activities in wheat and spinach plants. J. Plant Nutr. Soil Sci. 170, 288-295. doi: 10.1002/jpln.200625105

Campbell, R. (1989). Biological Control of Microbial Plant Pathogens. Cambridge, UK: Cambridge University Press.

Döbereiner, J. (1988). Isolation and identification of root associated diazotrophs. Plant Soil 110, 207-212.

Eckford, R., Cook, F. D., Saul, D., Aislabie, J., and Foght, J. (2002). Free-living heterotrophic nitrogen-fixing bacteria isolated from fuelcontaminated Antarctic soils. Appl. Environ. Microbiol. 68, 5181-5185. doi: 10.1128/AEM.68.10.5181-5185

Egamberdiyeva, D. (2007). The effect of plant growth promoting bacteria on growth and nutrient uptake of maize in two different soils. Appl. Soil Ecol. 36, 184-189. doi: 10.1016/j.apsoil.2007.02.005

Estrada, P., Mavingui, P., Cournoyer, B., Fontaine, F., Balandreau, J., and Caballero-Mellado, J. (2002). An $\mathrm{N}_{2}$-fixing endophytic Burkholderia sp. associated with maize plants cultivated in Mexico. Can. J. Microbiol. 48, 285-294. doi: 10.1139/w02-023

Kennedy, I. R., Choudhury, A., and Kecskés, M. L. (2004). Non-symbiotic bacterial diazotrophs in crop-farming systems: can their potential for plant growth promotion be better exploited? Soil Biol. Biochem. 36, 1229-1244. doi: 10.1016/j.soilbio.2004.04.006

\section{CONCLUSION}

It can be concluded that the selected diazotrophic isolates may be potentially beneficial biofertilizers and should be tested more in field conditions to confirm their potential to use as biofertilizers inoculants.

\section{ACKNOWLEDGMENTS}

We wish to acknowledge Matthew and Heather from microbiology department, UKZN, PMB campus, South Africa, for their assistance with the use of MALDI Biotyper and Mrs Susan Van der Merwe for her technical assistance with the greenhouse.

Khalid, A., Arshad, M., and Zahir, Z. (2004). Screening plant growth-promoting rhizobacteria for improving growth and yield of wheat. J. Appl. Microbiol. 96, 473-480. doi: 10.1046/j.1365-2672.2003.02161.x

Kloepper, J. W., Zablotowicz, R. M., Tipping, E. M., and Lifshitz, R. (1991). "Plant growth promotion mediated by bacterial rhizosphere colonizers," in The Rhizosphere and Plant Growth, eds L. Keister and P. B. Cregan (Dordrecht: Kluwer Academic Publishers), 315-326.

Knoth, J. L., Kim, S. H., Ettl, G. J., and Doty, S. L. (2013). Effects of cross host species inoculation of nitrogen-fixing endophytes on growth and leaf physiology of maize. GCB Bioenergy 5, 408-418. doi: 10.1111/gcbb.12006

Krotzky, A., and Werner, D. (1987). Nitrogen fixation in Pseudomonas stutzeri. Arch. Microbiol. 147, 48-57. doi: 10.1007/BF00492904

McCarty, G., and Meisinger, J. (1997). Effects of $\mathrm{n}$ fertilizer treatments on biologically active $\mathrm{N}$ pools in soils under plow and no tillage. Biol. Fertil. Soils 24, 406-412. doi: 10.1007/s003740050265

Meena, H., Sharma, G., Golada, S. L., and Jain, H. (2012). Yield and quality of sweet corn (Zea mays (L.) ssp. Saccharata) as affected by nitrogen levels, Azotobacter culture and nitrogen sources. Res. Crops 13, 486-492.

Mehnaz, S., Kowalik, T., Reynolds, B., and Lazarovits, G. (2010). Growth promoting effects of corn (zea mays) bacterial isolates under greenhouse and field conditions. Soil Biol. Biochem. 42, 1848-1856. doi: 10.1016/j.soilbio.2010.07.003

Mehnaz, S., and Lazarovits, G. (2006). Inoculation effects of Pseudomonas putida, Gluconacetobacter azotocaptans, and Azospirillum lipoferum on corn plant growth under greenhouse conditions. Microb. Ecol. 51, 326-335. doi: 10.1007/s00248-006-9039-7

Montañez, A., Blanco, A. R., Barlocco, C., Beracochea, M., and Sicardi, M. (2012). Characterization of cultivable putative endophytic plant growth promoting bacteria associated with maize cultivars (zeamays 1.) and their inoculation effects in vitro. Appl. Soil Ecol. 58, 21-28. doi: 10.1016/j.apsoil.2012. 02.009

Perin, L., Martínez-Aguilar, L., Paredes-Valdez, G., Baldani, J., Estrada-de Los Santos, P., Reis, V., et al. (2006). Burkholderia silvatlantica sp. nov., a diazotrophic bacterium associated with sugar cane and maize. Int. J. Syst. Evol. Microbiol. 56, 1931-1937. doi: 10.1099/ijs.0.64362-0

Reinhold-Hurek, B., and Hurek, T. (1998). Life in grasses: diazotrophic endophytes. Trends Microbiol. 6, 139-144. doi: 10.1016/S0966-842X(98) 01229-3

Riggs, P. J., Chelius, M. K., Iniguez, A. L., Kaeppler, S. M., and Triplett, E. W. (2001). Enhanced maize productivity by inoculation with diazotrophic bacteria. Funct. Plant Biol. 28, 829-836. doi: 10.1071/PP01045

Rodríguez-Blanco, A., Sicardi, M., and Frioni, L. (2015). Plant genotype and nitrogen fertilization effects on abundance and diversity of diazotrophic bacteria associated with maize (zea mays 1). Biol. Fertil. Soils 51, 391-402. doi: 10.1007/s00374-014-0986-8

Różycki, H., Dahm, H., Strzelczyk, E., and Li, C. Y. (1999). Diazotrophic bacteria in root-free soil and in the root zone of pine (Pinus sylvestris L) and oak (Quercus robur L). Appl. Soil Ecol. 12, 239-250. doi: 10.1016/S0929-1393(99) 00008-6 
Schepers, J., Francis, D., Vigil, M., and Below, F. (1992). Comparison of corn leaf nitrogen concentration and chlorophyll meter readings. Commun. Soil Sci. Plant Anal. 23, 2173-2187. doi: 10.1080/00103629209368733

Vessey, J. K. (2003). Plant growth promoting rhizobacteria as biofertilizers. Plant Soil 255, 571-586. doi: 10.1023/A:1026037216893

Wakelin, S. A., and Ryder, M. H. (2004). Plant growth-promoting inoculants in australian agriculture. Crop Manag. 3, 1-5. doi: 10.1094/cm-2004-0301-01-rv

Wu, S., Cao, Z., Li, Z., Cheung, K., and Wong, M. (2005). Effects of biofertilizer containing $\mathrm{N}$-fixer, $\mathrm{P}$ and $\mathrm{K}$ solubilizers and $\mathrm{AM}$ fungi on maize growth: a greenhouse trial. Geoderma 125, 155-166. doi: 10.1016/j.geoderma.2004. 07.003

Yobo, K., Laing, M., Hunter, C., and Morris, M. (2004). Biological control of Rhizoctonia solani by two Trichoderma species isolated from south african composted soil. S. Afr. J. Plant Soil 21, 139-144. doi: $10.1080 / 02571862.2004 .10635039$

Conflict of Interest Statement: The authors declare that the research was conducted in the absence of any commercial or financial relationships that could be construed as a potential conflict of interest.

Copyright (C) 2016 Kifle and Laing. This is an open-access article distributed under the terms of the Creative Commons Attribution License (CC BY). The use, distribution or reproduction in other forums is permitted, provided the original author(s) or licensor are credited and that the original publication in this journal is cited, in accordance with accepted academic practice. No use, distribution or reproduction is permitted which does not comply with these terms. 